\title{
Peripheral leucocyte count and longitudinal decline in lung function
}

\author{
MOIRA CHAN-YEUNG, RAJA ABBOUD, ANNE DY BUNCIO, SVERRE VEDAL \\ From the Respiratory Division, Department of Medicine, Vancouver General Hospital, Vancouver, Canada
}

\begin{abstract}
A six year follow up study of 750 aluminium smelter workers was undertaken to evaluate the relationship between the leucocyte count at the start of the study and the rate of decline in lung function. An inverse relationship between the leucocyte count and the forced expiratory volume in one second $\left(\mathrm{FEV}_{1}\right)$ and forced vital capacity (FVC) was present cross sectionally irrespective of cigarette smoking habit. The initial leucocyte count was also significantly related to the mean annuak decline in $\mathrm{FEV}_{1}$ in smokers $(\mathrm{p}=0.04)$ but not in former smokers or those who had never smoked These observations suggest that the leucocyte count is a factor influencing the annual decline in FEV $\overrightarrow{\hat{0}}$ in smokers.
\end{abstract}

It has been proposed that pulmonary emphysema develops as a result of an imbalance between elastase and antiproteases in the lung, leading to elastolytic lung injury. ${ }^{12}$ Cigarette smoking has been shown to be associated with high peripheral leucocyte counts. ${ }^{3-12}$ The number of neutrophils in the lungs was also shown to be greater in smokers than in non-smokers. ${ }^{13}$ Since polymorphonuclear leucocytes are likely to be the major source of elastase in the lung, the raised leucocyte count in smokers could be one mechanism by which cigarette smoking induces pulmonary emphysema.

In an earlier study we found an inverse relationship between the peripheral leucocyte count and the level of lung function irrespective of smoking habits. ${ }^{14}$ In a longitudinal study Sparrow and coworkers ${ }^{15}$ observed not only that there was an inverse relationship between the initial peripheral leucocyte count and initial lung function but also that the change in leucocyte count over 10 years was inversely related to lung function at follow up. These relationships were independent of smoking, suggesting that the peripheral leucocyte count was an important determinant of the level of lung function. We have evaluated the relationship between leucocyte count and the rate of decline in lung function in 750 smelter workers studied previously ${ }^{14}$ who had not changed their smoking habits when studied again six years later.

Address for reprint requests: Dr Moira Chan-Yeung, Respiratory Division, Vancouver General Hospital, Vancouver, British Columbia, Canada V5Z 3J5.

Accepted 17 February 1988

\section{Methods}

We conducted a follow up study of workers employed in an aluminium smelter six years after the initiat survey. Of the original cohort of 1620 male workers 904 remained; 750 workers had not changed theip smoking habits since the initial study. The participae tion rate of workers in both initial and follow up studies was over $85 \%$.

Details of the initial health study have been repor\% ted. $^{16}$ The same questionnaire on respiratory symp toms was used for the initial and follow up studies. $\mathrm{F}$ was derived from the American Thoracic Society Division of Lung Diseases respiratory questionnaire for epidemiological research. "Never smokers" wer\& subjects who had never smoked; former smokers weres subjects who had given up smoking for more than one. month before the initial survey; current smokers werf subjects who were smoking during the initial study and still smoking one month before the follow up study. O

Spirometric measurements were made at the plan $q^{2}$ site on both occasions with the same computerise rolling seal spirometer (Cardiopulmonary Ire struments, Houston, Texas). The mean force expiratory volume in one second $\left(\mathrm{FEV}_{1}\right)$, forced vitat capacity (FVC), and maximal mid expiratory flow rate $\left(\mathrm{FEF}_{25-75 \%}\right)$ were obtained from the two spirograms with the largest FVC values that agreed to within $3 \%$ of each other. All measurements were converted to BTPS.

Leucocyte counts were determined with a Coulter-\$ analyser during the initial survey, as described previously, ${ }^{14}$ but were not performed in the follow ug 
study. Measurements of air contaminants in the work environment were carried out by the Workers' Compensation Board of British Columbia during both health studies, both area and personal sampling being used. Workers were classified into different groups according to their job locations and industrial hygiene data. ${ }^{16}$

Standard statistical methods, such as analysis of variance, $\chi^{2}$ analysis, analysis of covariance, and multiple regression analysis ${ }^{18}$ were used to examine the interrelationships between leucocyte count, smoking, work exposure, and pulmonary function results. For analysing the relationship between initial leucocyte count and lung function or annual decline in lung function workers were divided by quintiles according to their leucocyte count.

\section{Results}

The results for the 750 workers who took part in the longitudinal study and who had not changed their smoking habits were analysed. At the time of the initial study the mean age was $37 \cdot 6$ (SD 10.2, range 18-59) years and the mean duration of employment in the smelter was 9.5 (SD 7.7, range $0 \cdot 2-26)$ years. There were 235 never smokers $(31 \cdot 3 \%), 231$ former smokers $(30.8 \%)$, and 284 current smokers $(37.9 \%)$. The workers were divided into three groups based on their work exposure. ${ }^{16}$ After adjusting for age, height, smoking, and racial group we were unable to detect

Table 1 Initial leucocyte counts (a) By age (adjusted for smoking)

\begin{tabular}{lcll}
\hline & \multicolumn{3}{l}{$\begin{array}{l}\text { Leucocyte count } \\
(\text { No/mm }\end{array}$} \\
\cline { 3 - 4 } Age (y) & $n$ & Mean & $S D$ \\
\hline 20 & 25 & 6428 & 1450 \\
$21-30$ & 196 & 6556 & 1530 \\
$31-40$ & 222 & 6659 & 1607 \\
$41-50$ & 216 & 6969 & 1774 \\
$51-60$ & 91 & 6705 & 1628 \\
\hline
\end{tabular}

(b) By smoking habit (adjusted for age)

\begin{tabular}{llll}
\hline & & \multicolumn{2}{l}{$\begin{array}{l}\text { Leucocyte count } \\
(\text { No/mm }\end{array}$} \\
\cline { 3 - 4 } & $n$ & Mean & $S D$ \\
\hline $\begin{array}{l}\text { Never smokers } \\
\text { Former smokers }\end{array}$ & 235 & 6113 & 1240 \\
$\begin{array}{l}\text { Current smokers } \\
\text { (cigarettes/day): }\end{array}$ & 231 & 6302 & 1385 \\
$<1$ pack of 20 & & & \\
$\quad$ 1 pack of 20 & 92 & 7197 & 1717 \\
$>1$ pack of 20 & 105 & 7621 & 1914 \\
\hline
\end{tabular}

Conversion: Traditional to SI units-1000 leucocytes $/ \mathrm{mm}^{3}=1.0 \times$ $10^{9} / 1$.

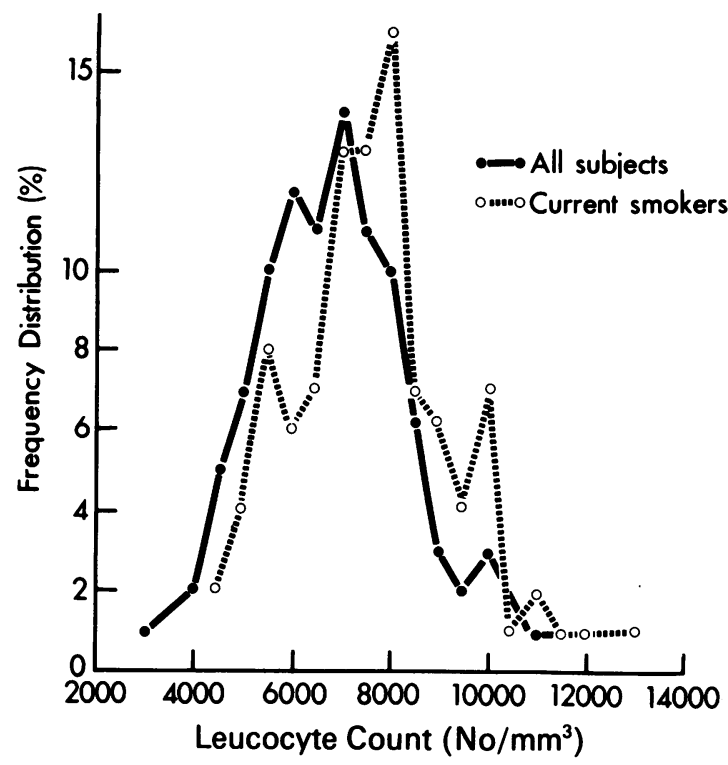

Fig 1 Frequency distribution of leucocyte count for all workers and separately for current smokers (1000 leucocytes) $\left.\mathrm{mm}^{3}=1.0 \times 10^{9} / \mathrm{l}\right)$.

significant differences in leucocyte count, baseline lung function, or annual decline in lung function between the different work groups. The three groups were therefore taken as one population for the analysis.

The initial leucocyte count was found to be positively correlated with age and smoking (both values $<0.001$ by analysis of covariance). Race had no effect on leucocyte count. Table $1 a$ shows the initial leucocyte count by age adjusted for smoking and table $1 b$ the initial leucocyte count by smoking habits. Current smokers had a significantly higher leucocyte count than never smokers. Among current smokers the higher the cigarette consumption the greater was the leucocyte count $(p<0.001)$. The frequency distribution of leucocyte counts in this population was normal, even among current smokers (fig 1).

Baseline pulmonary function results according to smoking habits and leucocyte count groups are shown in table 2; results are adjusted for age, height, and race. Within each smoking group workers with the lowest leucocyte count had the best baseline pulmonary function, and vice versa. Within each leucocyte count group the effect of smoking was not striking. The results of multiple regression analysis (table 3 ) confirmed these findings. Age, height, and race were correlated significantly with $\mathrm{FEV}_{\text {, }}$ and FVC, but smoking was not. Leucocyte count was related to baseline $F E V_{1}$ and $F V C$ after adjustment for the above variables $(p<0.001)$. There was a significant interaction between age and smoking for both current and 


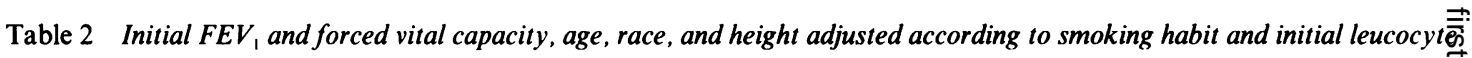
count

\begin{tabular}{|c|c|c|c|c|}
\hline $\begin{array}{l}\text { Leucocyte group } \\
\text { (by quintiles)* }\end{array}$ & $\begin{array}{l}\text { Never smokers } \\
(\text { mean }(S D)[n])\end{array}$ & $\begin{array}{l}\text { Former smokers } \\
(\text { mean }(S D)[n])\end{array}$ & $\begin{array}{l}\text { Current smokers } \\
(\text { mean }(S D)[n])\end{array}$ & $\begin{array}{l}\text { Total } \\
(\text { mean }(S D)[n])\end{array}$ \\
\hline $\begin{array}{l}\text { FEV }(\mathrm{ml}): \\
\text { 1st } \\
\text { 2nd } \\
\text { 3rd } \\
\text { 4th } \\
\text { 5th }\end{array}$ & $\begin{array}{ll}4125 & (606)[67] \\
4094 & (671)[64] \\
3888 & (665)[48] \\
3884 & (758)[38] \\
3887 & (920)[17]\end{array}$ & $\begin{array}{l}4161(758)[54] \\
4001(666)[66] \\
4051(818)[53] \\
3935(749)[31] \\
3953(744)[27]\end{array}$ & $\begin{array}{llll}4063 & (824) & {[29]} \\
3988 & (699) & {[35]} \\
3899 & (716) & {[51]} \\
3840 & (728) & {[68]} \\
3808 & (663) & {[101]}\end{array}$ & $\begin{array}{l}4112(704)[150] \\
4020(709)[165] \\
3945(738)[152] \\
3884(740)[138] \\
3869(709)[145]\end{array}$ \\
\hline $\begin{array}{l}\text { Forced vital capa } \\
\text { (ml): } \\
\text { 1st } \\
\text { 2nd } \\
\text { 3rd } \\
4 \text { th } \\
5 \text { th }\end{array}$ & $\begin{array}{ll}5102 & (769)[67] \\
5071 & (890)[64] \\
4841 & (771)[48] \\
4889 & (914)[39] \\
4899 & (1112)[17]\end{array}$ & $\begin{array}{l}5147(927)[54] \\
4915(716)[66] \\
5075(848)[53] \\
4082(838)[31] \\
4865(790)[27]\end{array}$ & $\begin{array}{lll}5171 & (1030) & {[29]} \\
4942 & (795) & {[35]} \\
4952 & (838) & {[51]} \\
4902 & (778) & {[68]} \\
4860 & (715) & {[101]}\end{array}$ & $\begin{array}{l}5142(878)[150] \\
4981(836)[165] \\
4960(829)[152] \\
4880(842)[138] \\
4865(778)[145]\end{array}$ \\
\hline
\end{tabular}

${ }^{*}$ Groups according to leucocyte quintiles: $1-<5320 ; 2-5321-6200 ; 3-6201-7000 ; 4-7001-7800 ; 5->7800 / \mathrm{mm}^{3}$.

Conversion: Traditional to SI units-1000 leucocytes $/ \mathrm{mm}^{3}=1.0 \times 10^{9} / 1$.

former smokers when the analysis was repeated to include age and smoking interaction terms, and the leucocyte count was still significantly related to the baseline $\mathrm{FEV}_{1}$ and FVC.

The relationship between leucocyte count and the

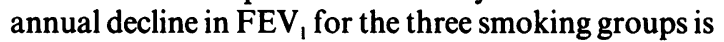
shown in figure 2 . When multiple regression analysis was carried out for each smoking group with age and race taken into account (table 4) a significant relationship between initial leucocyte count and annual decline in $\mathrm{FEV}_{\text {, }}$ was observed in current smokers only. Although the trend was observed for never smokers, the relationship did not reach statistical significance.

In current smokers the number of cigarettes smoked daily was an independent predictor of lung function decline $(p=0.045)$. There was no interaction between the number of cigarettes smoked daily and leucocyte count on the annual rate of $\mathrm{FEV}_{1}$ decline-that is, the association between increased leucocyte count and a more rapid rate of decline was not limited to the heavily smoking group of cigarette smokers.

\section{Discussion}

In this study of 750 aluminium smelter workers who had not changed their smoking habits, and who hach spirometry repeated six years after the initial study, $\frac{14}{6}$ we found that the initial leucocyte count was not onlpo inversely related to the initial lung function $\left(\mathrm{FEV}_{1}\right.$ and FVC) but was also related to the subsequent annuab decline in lung function. Our findings of a relationshis between a high leucocyte count and a greater lon gitudinal decline in lung function are in accord wit/ those of Sparrow and coworkers. ${ }^{15}$ In our study thi@ relationship was found only in current smoker $\vec{B}$ whereas in the study by Sparrow et $a l^{15}$ the relationship was found in all smoking groups. The difference between the two studies could be due to the smaller. number of subjects in our population.

The importance of the leucocyte count as a factoo affecting the decline in lung function was indicated b the fact that the differences in decline in lung functiog between current and never smokers were not eviden when the leucocyte count was taken into accoun Moreover, former smokers had leucocyte count\$ similar to those of never smokers and their initial lung function and subsequent annual decline in lung funco tion were not very different from those of never. smokers. At the time of the follow up study the formes smokers had given up smoking for at least six years, sö

Table 3 Regression of initial pulmonary function on selected initial variables in 750 subjects

\begin{tabular}{|c|c|c|c|c|c|c|}
\hline & \multicolumn{3}{|l|}{$F E V_{1}(m l)$} & \multicolumn{2}{|c|}{ Forced vital capacity $(\mathrm{ml})$} & $\stackrel{0}{\varepsilon}$ \\
\hline & $\begin{array}{l}\text { Regression } \\
\text { coefficient }\end{array}$ & $\begin{array}{l}\text { Standard } \\
\text { error }\end{array}$ & $p$ value & $\begin{array}{l}\text { Regression } \\
\text { coefficient }\end{array}$ & $\begin{array}{l}\text { Standard } \\
\text { error }\end{array}$ & p value \\
\hline $\begin{array}{l}\text { Age (y) } \\
\text { Height (cm) }\end{array}$ & $\begin{array}{r}-35 \cdot 70 \\
41 \cdot 51\end{array}$ & $\begin{array}{l}1.93 \\
2.85\end{array}$ & $\begin{array}{l}<0.001 \\
<0.001\end{array}$ & $\begin{array}{r}-28 \cdot 79 \\
62 \cdot 42\end{array}$ & $\begin{array}{l}2 \cdot 26 \\
3 \cdot 33\end{array}$ & $\begin{array}{l}<0.01 \text { 票 } \\
<0.001{ }^{\circ}\end{array}$ \\
\hline $\begin{array}{l}\text { Smoking: } \\
\text { Current smokers } \\
\text { Former smokers } \\
\text { Non-white } \\
\text { Initial leucocyte count }\left(\times 10^{3} / \mathrm{mm}^{3}\right) \text {, } \\
\text { Constant }\end{array}$ & $\begin{array}{r}-59.96 \\
38.52 \\
-471.76 \\
-48.63 \\
-1565.41\end{array}$ & $\begin{array}{r}51 \cdot 60 \\
51 \cdot 30 \\
63 \cdot 10 \\
12 \cdot 70 \\
527 \cdot 22\end{array}$ & $\begin{aligned} & 0.25 \\
& 0.46 \\
< & 0.001 \\
< & 0.001 \\
< & 0.005\end{aligned}$ & $\begin{array}{r}-9 \cdot 76 \\
16 \cdot 70 \\
-656 \cdot 90 \\
-48 \cdot 88 \\
-4451 \cdot 48\end{array}$ & $\begin{array}{r}59 \cdot 66 \\
59 \cdot 55 \\
72 \cdot 96 \\
14 \cdot 77 \\
609 \cdot 57\end{array}$ & 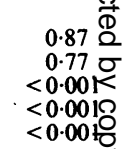 \\
\hline
\end{tabular}


Annual Change

in $\mathrm{FEV}_{1}(\mathrm{ml})$

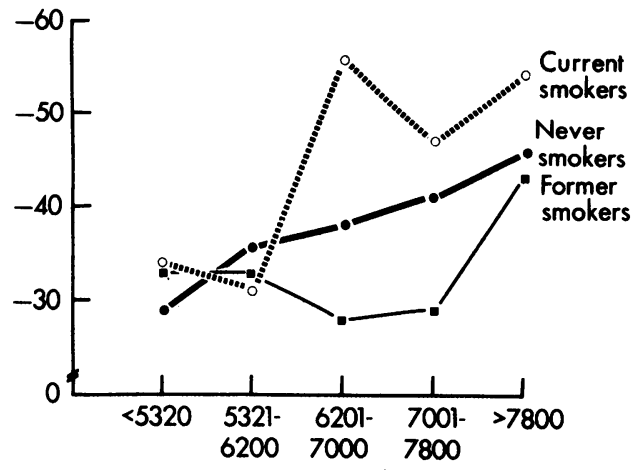

Leucocyte Count by Quintiles $\left(\mathrm{No} / \mathrm{mm}^{3}\right)$

Fig 2 Relationship between mean annual change in FEV (adjusted for age and race) and peripheral leucocyte count according to cigarette smoking habit. The leucocyte count groups are in quintiles (1000 leucocytes $\left./ \mathrm{mm}^{3}=1.0 \times 10^{9} / \mathrm{l}\right)$.

their similarity to never smokers is not surprising.

The time interval between blood sampling and the last cigarette smoked was not noted in this study. The timing of blood sampling is unlikely, however, to have influenced our findings, as we found no correlation between the leucocyte count in smokers and the time interval between blood sampling and the last cigarette smoked in 162 male workers. ${ }^{19}$. The long term stability of leucocyte counts is not known. Sparrow and coworkers ${ }^{15}$ performed leucocyte counts during both initial and follow up visits in their study; the stability of the leucocyte count was not explored. Among current smokers, however, the count must remain raised.

The mechanisms leading to an association between a raised leucocyte count and a greater decline in $\mathrm{FEV}_{1}$ are not clear. In smokers the peripheral leucocyte count may be related to the degree of inflammation in small airways, which has been shown to be related to abnormalities in small airway function. ${ }^{2021}$ In a study of 162 non-occupationally exposed white $\operatorname{men}^{19}$ we showed that it was the neutrophil count that led to the association between leucocyte count and lung function in smokers; there was no association between lung function and other leucocyte cell types. We did not determine the differential white cell count in the present study, but increased leucocyte counts in smokers have been shown to be due to an increase in neutrophils. ${ }^{519}$ Although in our previous study ${ }^{19}$ lung function in smokers was related to neutrophil counts, it was not related to neutrophil elastase concentrations.

These findings fit the proteolytic hypothesis of the development of emphysema if in smokers damage to airways and terminal lung units is more dependent on the degree of inflammatory reaction than on the elastase content of neutrophils. Although the elastase content per neutrophil was not increased in smokers, the total amount of elastase in the lung potentially available for inducing proteolytic injury would be increased because of the increased number of neutrophils in the lungs of smokers. ${ }^{13}$ The increased numbers of neutrophils in smokers may also contribute to protease-antiprotease imbalance by oxidative inactivation of $\alpha_{1}$ protease inhibitor through myeloperoxidase or superoxide release. These two potential mechanisms are supported by the finding of an association between smoking and increased neutrophil myeloperoxidase activity, ${ }^{22}$ and by the report of increased generation of superoxide anion by stimulated neutrophils in smokers with leucocyte counts over $9.0 \times 10^{9} / 1 .^{23}$

The relationship between lung function and leucocyte (neutrophil) count may depend on mechanisms other than protease-antiprotease imbalance. Airway reactivity may be related to airway inflammation, as suggested by animal studies, ${ }^{24}$ and thus to peripheral blood leucocyte counts. There was no apparent relationship, however, between neutrophil or leucocyte blood counts and bronchial reactivity in an epidemiological survey of woodmill workers. ${ }^{25}$ The adverse effect of leucocytes on airway function may be mediated through other mechanisms, such as the release of chemical mediator $\mathrm{s}^{26}$ or the release of oxygen radicals. ${ }^{27}$ An increased leucocyte count could also reflect infection, which might be related to lung function decline. Finally, the relation between a raised leucocyte count and increased $\mathrm{FEV}_{1}$ decline may not be causal but may be an association related to

Table 4 Regression of annual change in FEV, on leucocyte count according to cigarette smoking habit

\begin{tabular}{|c|c|c|c|c|c|c|c|c|c|}
\hline \multirow[b]{2}{*}{ Variable } & \multicolumn{3}{|c|}{ Never smokers } & \multicolumn{3}{|c|}{ Former smokers } & \multicolumn{3}{|c|}{ Current smokers } \\
\hline & $B$ & $S E M$ & $p$ & $B$ & $S E M$ & $p$ & $B$ & $S E M$ & $p$ \\
\hline $\begin{array}{l}\text { Age } \\
\text { Non-white } \\
\text { Leucocyte count }\end{array}$ & $\begin{array}{r}-1.00 \\
0.70\end{array}$ & $\begin{array}{l}0.27 \\
5.95\end{array}$ & $\begin{array}{c}<0.001 \\
0.91\end{array}$ & $\begin{array}{r}-0.62 \\
8.23\end{array}$ & $\begin{array}{r}0.32 \\
13.05\end{array}$ & $\begin{array}{l}0.04 \\
0.53\end{array}$ & $\begin{array}{r}-1.43 \\
2.86\end{array}$ & $\begin{array}{l}0 \cdot 214 \\
12 \cdot 0\end{array}$ & $\begin{array}{c}<0.001 \\
0.81\end{array}$ \\
\hline $\begin{array}{l}\left(\times 10^{3} / \mathrm{mm}^{3}\right) \\
\text { Constant }\end{array}$ & $\begin{array}{r}-3.00 \\
-53.53\end{array}$ & $\begin{array}{r}2.08 \\
71.72\end{array}$ & $\begin{array}{l}0.12 \\
0.46\end{array}$ & $\begin{array}{r}-1.07 \\
53.64\end{array}$ & $\begin{array}{r}2 \cdot 21 \\
84 \cdot 28\end{array}$ & $\begin{array}{l}0.63 \\
0.52\end{array}$ & $\begin{array}{l}-3.43 \\
120 \cdot 7\end{array}$ & $\begin{array}{l}1 \cdot 38 \\
66 \cdot 6\end{array}$ & $\begin{array}{r}<0.02 \\
0.07\end{array}$ \\
\hline
\end{tabular}


smoking. For example, leucocytosis may be a marker for cigarette smoking dose and may therefore be a better measure of the duration and dose effect of smoking than estimates based on cigarette consumption. Further work is needed to explore the relation between leucocyte count and lung function.

This work was supported in part by the Workers' Compensation Board of British Columbia.

\section{References}

1 Mittman C. Summary of symposium on pulmonary emphysema and proteolysis. Am Rev Respir Dis 1972;105:430-48.

2 Janoff A. Biochemical links between cigarette smoking and pulmonary emphysema. J Appl Physiol 1983; 55:285-93.

3 Banks DC. Smoking and leucocyte-counts. Lancet 1971;ii:815.

4 Billimoria JD, Pozner H, Metselaar B, Best FW, James DCO. Effect of cigarette smoking on lipids, lipoproteins, blood coagulation, fibrinolysis and cellular components of human blood. Atherosclerosis 1975;21:61-76.

5 Corre F, Lellouch J, Schwartz D. Smoking and leucocyte counts. Results of an epidemiological survey. Lancet 1971;ii:632-4.

6 Friedman GD, Siegelaub AB, Seltzer CC, Feldman R, Collen MF. Smoking habits and the leucocyte count. Arch Environ Health 1973;26:137-43.

7 Helman N, Rubenstein LS. The effects of age, sex, and smoking on erythrocytes and leucocytes. Am J Clin Pathol 1975;63:35-44.

8 Howell RW. Smoking habits and laboratory tests. Lancet 1970;ii:152-3.

9 Okuno T. Smoking and blood changes. JAMA 1973;225:1387-8.

10 Noble RC, Penny BB. Comparison of leucocyte count and function in smoking and nonsmoking young men. Infect Immun 1975;12:550-5.

11 Chan-Yeung M, Ferreira P, Frohlich J, Schulzer M, Tan F. The effects of age, smoking and alcohol on routine laboratory tests. Am J Clin Pathol 1981;75:320-6.

12 Petitti DB, Kipp H. The leucocyte count: association with intensity of smoking and persistence of effect after quitting. Am J Epidemiol 1986;123:89-95.

13 Hunninghake GW, Crystal RG. Cigarette smoking and lung destruction. Accumulation of neutrophils in the $\overrightarrow{\vec{F}}$ lungs of cigarette smokers. Am Rev Respir Dis 1983;128:833-8.

14 Chan-Yeung M, DyBuncio A. Leucocyte count, smok- $\frac{\bar{V}}{\bar{D}}$ ing, and lung function. Am J Med 1984;76:31-7.

15 Sparrow D, Glynn RJ, Cohen M, Weiss ST. The relation- $\stackrel{\mathbb{Q}}{\Omega}$ ship of the peripheral leucocyte count and cigarette smoking to pulmonary function among adult men. Chest 1984;86:383-6.

16 Chan-Yeung $\mathrm{M}$, Wong $\mathrm{R}$, MacLean $\mathrm{L}$, et al. $\overrightarrow{\vec{H}}$ Epidemiologic health study of workers in an aluminium smelter in British Columbia. Effects on the respiratory system. Am Rev Respir Dis 1983;127:465-9.

17 Ferris B. Recommended Respiratory Disease Question- $\vec{\omega}$ naire for Use with Adults and Children in $\sigma$ Epidemiological Research. Am Rev Respir Dis $\vec{\sigma}$ 1978;118:7-54

18 Dixon WJ, Massey FJ. Introduction to statistical analysis. 윽 4th ed. New York: McGraw-Hill, 1983:241.

19 Abboud RT, Richter A, Vedal S, Fera T, Johal S, ChanYeung M. Relationship between leucocyte count, neutrophil elastase content, smoking and lung function [abstract]. Am Rev Respir Dis 1986;133:A391.

20 Cosio M, Ghezzo H, Hogg JC, et al. The relations $\infty$ between structural changes in small airways and pulmonary function tests. $N$ Engl $J$ Med 1977;298: 1277-81.

21 Wright JL, Lawson LM, Pare PD, Kennedy S, Wiggs B, Hogg JC. The detection of small airways disease. Am Rev Respir Dis 1984;129:989-94.

22 Bridges RB, Fu MC, Rehm SR. Increased neutrophil $\overrightarrow{\bar{O}}$ myeloperoxidase activity associated with cigarette smoking. Eur J Respir Dis 1985;65:84-93.

23 Ludwig PW, Hoidal JR. Alterations in leucocyte oxidative metabolism in cigarette smokers. Am Rev Respir Dis 1982;126:977-80.

24 Holtzman MJ, Fabbri LM, O’Byrne PM, et al. Importance of airway inflammation for hyperresponsiveness induced by ozone. Am Rev Respir Dis 1983;127:686-90.

25 Abboud RT, Enarson E, Vedal S, Yeung M. Relationship between leucocyte blood counts and bronchial reactivity in woodmill workers [abstract]. Clin Invest Med 1985;8:A204.

26 Geotzl EJ. Oxygenation products of arachidonic acid as mediators of hypersensitivity and inflammation. Med Clin North Am 1981;65:809-28.

27 McCord JM, Wong K. Phagocyte-produced free $\mathrm{N}$ radicals: roles in cytotoxicity and inflammation. In: $N$ Fitzsimons DW, ed. Ciba Foundation symposium. 요 Oxygen free radicals and tissue damage. Amsterdam: $\omega$ Excerpta Medica, 1979:343-60. 